\title{
Tax-adjusted discount rates with investor taxes and risky debt
}

\author{
Cooper, Ian A ; Nyborg, Kjell G
}

\begin{abstract}
This paper derives a tax-adjusted discount rate formula with a constant proportion leverage policy, investor taxes, and risky debt. The result depends on an assumption about the treatment of taxlosses in default. We identify the assumption that justiftes the textbook approach of discounting interest tax shields at the cost of debt. We contrast this with an alternative assumption that leads to the Sick (1990) result that these should be discounted at the riskless rate. These two approachesrepresent polar cases. Each generates its results by using a different simplifying assumption, and we explain what determines the correct treatment in practice. We also discuss implementation of the valuation procedure using the capital asset pricing model.
\end{abstract}

DOI: https://doi.org/10.1111/j.1755-053X.2008.00016.x

Posted at the Zurich Open Repository and Archive, University of Zurich

ZORA URL: https://doi.org/10.5167/uzh-61726

Journal Article

Published Version

Originally published at:

Cooper, Ian A; Nyborg, Kjell G (2008). Tax-adjusted discount rates with investor taxes and risky debt. Financial Management, 37(2):365-379.

DOI: https://doi.org/10.1111/j.1755-053X.2008.00016.x 


\title{
Tax-Adjusted Discount Rates with Investor Taxes and Risky Debt
}

\author{
Ian A. Cooper and Kjell G. Nyborg*
}

\begin{abstract}
This paper derives a tax-adjusted discount rate formula with a constant proportion leverage policy, investor taxes, and risky debt. The result depends on an assumption about the treatment of tax losses in default. We identify the assumption that justifies the textbook approach of discounting interest tax shields at the cost of debt. We contrast this with an alternative assumption that leads to the Sick (1990) result that these should be discounted at the riskless rate. These two approaches represent polar cases. Each generates its results by using a different simplifying assumption, and we explain what determines the correct treatment in practice. We also discuss implementation of the valuation procedure using the capital asset pricing model.
\end{abstract}

The treatment of the tax saving from debt in company valuation has recently been of renewed interest (Fernandez, 2004; Cooper and Nyborg, 2006). However, there is still no standard approach to calculating tax-adjusted discount rates when debt is risky. There are two factors that complicate the analysis: 1) the yield spread on corporate debt and 2) investor taxes. The yield spread can be a significant part of the cost of capital for some firms, especially with the high leverage and low equity risk premia that are often used. Investor taxes can also have a significant impact. Evidence from the United States prior to the tax reforms of 2003 is inconclusive about the degree to which investor taxes offset the corporate tax advantage to borrowing. Fama and French (1998) present empirical evidence consistent with a large impact of investor taxes, whereas Kemsley and Nissim (2002) find little effect. ${ }^{1}$ However, the recent changes to the US Tax Code have increased the impact of investor taxes on the value of leveraged firms. Also, countries with imputation taxes have an effect of investor taxes built directly into their tax systems (Rajan and Zingales, 1995).

There are several alternative approaches to these issues. Assuming a constant leverage ratio, Miles and Ezzell (1980) derive a well-known formula for tax-adjusted discount rates. The MilesEzzell ("ME") formula allows for risky debt, but not investor taxes. Taggart (1991) derives a variation of it that allows for investor taxes but assumes that corporate debt is riskless. Sick (1990) develops a valuation formula that takes into account both investor taxes and the yield spread on debt. He contrasts this with a version of the ME formula given in Brealey and Myers (2003), which includes an adjustment for investor taxes. According to Sick, the formula given by Brealey and Myers (2003) differs from his “. . . by the incorrect treatment of risky debt, as well as the failure to recognize that tax shields should be discounted at a cost of equity..." (Sick, 1990,

We are grateful to an anonymous referee, Huang Wei Bin. and Bill Christie (the editor) for helpful suggestions. All remaining errors are ours.

"Ian A. Cooper is Professor at the London Business School in London, UK. Kjell G. Nyborg is DnBNOR Professor of Finance at the Norwegian School of Economics in Bergen, Norway and a research fellow of CEPR.

'Graham (2000) finds that the net tax advantage to debt is less than the full corporate tax rate because of nondebt tax shields. The valuation consequences of this are more complicated as it implies that the tax rate that should be used in valuation is state and time dependent. 
p. 1441). The Sick approach is also different from the standard ME formula without investor taxes. Sick's formula differs from theirs because he discounts tax shields at a different rate.

These different approaches can lead to economically significantly different discount rates and values. Understanding when the various formulas apply is, therefore, important. In this paper, we first clarify the source of the difference between the approaches of Sick (1990) and ME. We describe the underlying assumptions that can be used to justify their different methods. Which approach is appropriate depends upon the tax position of insolvent firms and the tax treatment of debt write-downs. We then use the assumption that is consistent with the ME approach to derive a formula for tax-adjusted discount rates that includes investor taxes and risky debt. The formula is the same as Taggart's (1991) when debt is risk free. It is similar, but not identical, to Brealey and Myers' (2003) formula. It turns out that Brealey and Myers' (2003) intuitive formula is not exactly correct as it does not include all the effects of investor taxes. Finally, we provide consistent expressions for the asset beta and discuss implementation using the capital asset pricing model $(\mathrm{CAPM})^{2}$

\section{The Tax-Adjusted Discount Rate}

We operate under the Miles and Ezzell (1980) leverage assumption that leverage is maintained at a constant proportion of the market value of the firm. This is the most realistic simple leverage policy, and also the one that is consistent with the use of the weighted average cost of capital $(W A C C)$. The ME formula applies to any profile of cash flows as long as the company maintains constant market value leverage. It provides a relationship between the leveraged discount rate, $R_{L}$, and the unleveraged rate, $R_{U}$. We analyze a firm with expected pre-tax cash flows $C_{t}$, at dates $t=1, \ldots, T$. Between these dates, leverage remains fixed. After each cash flow, leverage is reset to a constant proportion, $L$, of the leveraged value of the firm. The two rates, $R_{U}$ and $R_{L}$, are defined implicitly as the discount rates that give the correct unleveraged and leveraged values when the after-tax operating cash flows are discounted: ${ }^{3}$

$$
\begin{aligned}
& V_{U t}=\sum_{i=t+1}^{T} C_{i}\left(1-T_{C}\right) /\left(1+R_{U}\right)^{i} \quad t=1, \ldots, T \\
& V_{L t}=\sum_{i=t+1}^{T} C_{i}\left(1-T_{C}\right) /\left(1+R_{L}\right)^{i} \quad t=1, \ldots, T,
\end{aligned}
$$

where $V_{U t}$ is the unleveraged value of the firm and $V_{L t}$ its leveraged value.

We assume that the representative investor has tax rates of $T_{P D}$ on interest income and $T_{P E}$ on the total of equity income and capital gains. The use of a single rate for equity returns is a simplification, but our focus here is not the details of the investor tax system. Analysis of the implications of differential investor income and capital gains rates can be found in Lewellen and Lewellen (2005). With our assumptions, the increase in the after-tax cash flow to the representative investor resulting from an incremental dollar of corporate interest is:

$$
T_{S}=\left(1-T_{P D}\right)-\left(1-T_{C}\right)\left(1-T_{P E}\right)
$$

\footnotetext{
${ }^{2}$ More complex capital structure issues in the presence of investor taxes are discussed in Emery and Gehr (1988).

${ }^{3}$ We assume that tax is levied on the operating cash flows. A more complex treatment does not alter the results.
} 
This result is standard. We define the related variable, $T^{*}$, by:

$$
T^{*}=T_{S} /\left(1-T_{P D}\right)
$$

Thus:

$$
1-T^{*}=\frac{\left(1-T_{C}\right)\left(1-T_{P E}\right)}{1-T_{P D}} .
$$

Following Taggart (1991), we define the required return on riskless equity as

$$
R_{F E}=\frac{R_{F}\left(1-T_{P D}\right)}{\left(1-T_{P E}\right)}=\frac{R_{F}\left(1-T_{C}\right)}{\left(1-T^{*}\right)} .
$$

The first equality results from setting the after-investor-tax returns on riskless debt and riskless equity equal to each other. The second equality follows from Equation (5). Note that if $T_{P D}$ and $T_{P E}$ are equal, then $R_{F E}=R_{F}$.

The equation that relates $R_{U}$ and $R_{L}$ is one of the most important in valuation. It is used whenever discount rates are adjusted to reflect a different amount of leverage. Even when adjusted present value methods are used to take into account the tax saving from debt, this relationship may first be used to derive the unlevered required return. The original ME formula that relates $R_{U}$ and $R_{L}$ was derived with an informal treatment of risky debt and no investor taxes. It is dependent upon the "cost of debt" where this could be interpreted either as the yield or the expected return. For clarity, we define the yield on the debt as $Y_{D}$, and the expected return on the debt as $R_{D}{ }^{4}$ The difference is the effect of expected default. ${ }^{5}$ Miles and Ezzell (1980) present the relationship between $R_{U}$ and $R_{L}$ as

$$
R_{L}=R_{U}-\frac{L Y_{D} T_{C}\left(1+R_{U}\right)}{1+Y_{D}}
$$

where their "cost of debt" has been interpreted here as its yield. Brealey and Myers (2003) generalize this to the case of investor taxes by using $T^{*}$ rather than $T_{C}$ :

$$
R_{L}=R_{U}-\frac{L Y_{D} T^{*}\left(1+R_{U}\right)}{1+Y_{D}}
$$

Sick (1990) derives a different relationship: ${ }^{6}$

$$
R_{L}=R_{U}-\frac{L R_{F E} T^{*}\left(1+R_{U}\right)}{1+R_{F E}} .
$$

The key difference, as noted by Sick, is that his result in Equation (9) involves the use of the riskless equity rate rather than the cost of debt that is in Equation (8). If the investor tax rate is set to zero, we see that Sick's formula also differs from ME's in Equation (7).

\footnotetext{
${ }^{4}$ In particular, $Y_{D}$ is the coupon on debt issued at par.

${ }^{5}$ See Cooper and Davydenko (2007) for a more extensive discussion of this point.

${ }^{6}$ The notation in Sick (1990) is slightly different, but the result can be derived by simple substitution. Equation (9) is also the formula derived by Taggart (1991) when debt is riskless.
} 


\section{The Assumptions Underlying the Different Approaches}

In this section, we show that the difference between the Sick (1990) and ME formulas concerns an assumption about the tax treatment of insolvent firms. Sick assumes that an insolvent firm will make a tax payment equal to the gain from writing off its debt multiplied by the tax rate. If the write-off is total, the entire principal of the debt will be taxed when the firm defaults. As we show below, the assumption implicit in the ME approach is that no such payment will be made. The issue in choosing between the two approaches is, therefore, whether insolvent firms can be expected to make such tax payments. At the end of this section, we discuss the factors that affect this.

We show the impact of the different assumptions using a one-period two-state model. To focus on the fundamental difference between the two approaches, in this illustration there are no investor taxes. Later we derive the results including investor taxes. Table I demonstrates the valuation of the debt tax shield under two alternative assumptions about the tax savings from interest. The valuation is by no-arbitrage, using a riskless bond and the risky bond to span the tax saving. Panel A shows the prices and payoffs of the riskless and risky bonds. The risky bond either makes its promised payment of $1+Y_{D}$ if it does not default, or defaults completely.

Panel $B$ indicates the valuation by no-arbitrage of the tax savings from interest assumed by Sick (1990). The tax impact of borrowing is $T_{C} Y_{D}$ per dollar of the face value of the bond if the company is solvent, but the company pays $T_{C}$ as a consequence of the debt if it defaults. The latter payment is caused by the gain from writing off the bond. To replicate the tax consequences of the debt, the replicating portfolio consists of an amount $T_{C}$ of the risky bond and riskless borrowing of $\mathrm{T}_{C} /\left(1+R_{F}\right)$. This gives the same payoff as the incremental tax effect of the debt. The value of the tax saving, $P V T S_{S}$, is simply the value of this replicating portfolio:

$$
P V T S_{S}=T_{C} R_{F} /\left(1+R_{F}\right) .
$$

Panel $\mathrm{C}$ shows the no-arbitrage valuation of the ME tax savings from interest. This differs from the Sick (1990) tax savings in that there is no tax payment when the company is in default, as the company is assumed to pay no tax in this state. The replicating portfolio consists of $T_{C} Y_{D} /(1+$ $Y_{D}$ ) invested in the risky bond. The resulting value of the tax shield from debt is simply the value of this investment:

$$
\text { PVTS }_{M E}=T_{C} Y_{D} /\left(I+Y_{D}\right) .
$$

Although Table I uses a single-period model, this valuation procedure is also correct in the multi-period setting we use in the remainder of this paper.

As seen above, both polar approaches generate simple results at the expense of simplifying assumptions. The correct treatment in practice will depend on which is closer to the actual tax impact of debt for insolvent companies. An important factor here is how the tax code treats debt write-downs. As discussed by Miller (1991), in the United States, a cancellation of indebtedness (COD) gives rise to a tax liability (IRC Section 61(a)(12)). This is also what is assumed by Sick (1990), but not by the ME approach. However, the tax code also grants an exception from tax on COD if the firm is insolvent in the sense that liabilities exceed assets (see Miller, 1991; United States Tax Court, 2006). ${ }^{7}$ Thus, tax on COD is an issue only for firms seeking debt forgiveness

\footnotetext{
${ }^{7}$ Firms for which tax on COD is an issue can avoid the tax by reorganizing in Chapter 11 (Miller, 1991). The evidence suggests though that tax on COD is not an issue for many firms that reorganize in Chapter 11. For example, Betker (1995) finds that in none of the 41 pre-packaged Chapter 11 's in his sample would the firm actually incur tax on COD, and Gilson (1997) provides some evidence that potential tax on COD does not affect the amount of debt reductions incurred by reorganizing distressed firms.
} 
Table I. Illustration of the Difference in Tax Shield Valuation with Alternative Approaches to the Tax Treatment of Insolvent Firms

Time 0 Value

Time 1 Cash Flow

If Solvent

If Insolvent

\begin{tabular}{lccc}
\hline \multicolumn{1}{c}{ Panel A. Primitive Assets } & \\
\hline \hline Riskless asset & 1 & $1+R_{F}$ & $1+R_{F}$ \\
Bond & 1 & $1+Y_{D}$ & 0 \\
\hline \hline
\end{tabular}

Panel B. No-Arbitrage Valuation of Tax Saving with Tax Payment in Insolvency (Sick, 1990)

\begin{tabular}{lccc}
\hline \hline Tax saving & $P V T S_{S}$ & $T_{C} Y_{D}$ & $-T_{C}$ \\
Replicating portfolio & $T_{C}-T_{C} /\left(1+R_{F}\right)$ & $T_{C}\left(1+Y_{D}\right)-T_{C}$ & $-T_{C}$ \\
\hline \hline
\end{tabular}

Panel C. No-Arbitrage Valuation of Tax Saving with No Tax Payment in Insolvency (Miles and Ezzell, 1980)

\begin{tabular}{lccc}
\hline \hline Tax saving & $P V T S_{M E / B M}$ & $T_{C} Y_{D}$ & 0 \\
Replicating portfolio & $T_{C} Y_{D} /\left(1+Y_{D}\right)$ & $T_{C} Y_{D}$ & 0 \\
\hline \hline
\end{tabular}

without being legally insolvent. Both the Sick and ME approaches implicitly assume that debt write-downs occur only in the case of insolvency. Consequently, Sick's approach is not consistent with US tax law, whereas the ME approach is.

In the remainder of this paper, we derive valuation formulas under the ME assumption. Therefore, we assume that the tax savings from risky debt should be valued using Equation (11). As illustrated in Table I, this represents one extreme assumption about the treatment of the COD. This assumption is closer to the US Tax Code than Sick's (1990) assumption, but the latter may be more appropriate in other jurisdictions.

Sick's (1990) analysis may be relevant in jurisdictions where tax law does not provide an exception from tax on COD to insolvent firms. In such cases, Sick's approach is correct if insolvent firms are in tax-paying positions. However, based on US evidence, insolvent firms typically do not pay taxes (Gilson, 1997). Therefore, the principal mechanism for the incremental tax payment from COD in the insolvent state that Sick assumes must be a reduction in the value of carried-forward tax losses. Whether this is realistic depends on a variety of factors, including the efficiency of the market for tax loss transfers. Imperfections in this market would imply that Sick's approach needs modification even when COD is taxed when the firm is insolvent.

The ME approach is most relevant in jurisdictions such as in the United States where tax law provides an exception from tax on COD for insolvent firms. However, if default implies only a partial loss on the bond, the ME approach is also incomplete in that setting. In general, it is likely that the correct treatment lies somewhere between the two polar cases. ${ }^{8}$

\footnotetext{
${ }^{8}$ There is an interesting theoretical problem with the combination of a constant leverage policy and default. If a firm continuously maintains a constant leverage ratio and there are no jumps in its value, it will never default. Of course, default is possible without jumps if leverage is adjusted only periodically, as in the original setup of Miles and Ezzell (1980).
} 


\section{The Relationship between Leveraged and Unleveraged Rates}

Appendix A demonstrates that under the standard $\mathrm{ME}$ assumptions with the inclusion of risky debt and investor taxes, the relationship between $R_{L}$ and $R_{U}$ is:

$$
R_{L}=R_{U}-\left[L Y_{D} T^{*}\left(1+R_{U}\right) /\left(1+Y_{D}\right)\right]\left[\left(1-T_{C}\right) /\left(1-T^{*}\right)\right]\left[\left(1+R_{F}\right) /\left(1+R_{F E}\right)\right] .
$$

For instance, if $T^{*}=T_{C}$ because there are no investor taxes, this formula is equal to the standard ME result in Equation (7). The difference from Brealey and Myers' (1988) expression, Equation (8), lies in the second and third terms in square brackets. They do not include these terms in their intuitively derived expression with investor taxes.

If the debt is riskless, then $Y_{D}=R_{F}$ and

$$
R_{L}=R_{U}-\frac{L R_{F E} T^{*}\left(1+R_{U}\right)}{\left(1+R_{F E}\right)} .
$$

This is the expression given in Sick (1990) for risky debt and in Taggart (1991) for riskless debt. Thus, the difference from Sick's results lies in the treatment of the debt yield spread, as discussed above.

If the period between rebalancing the leverage becomes short, Equation (12) converges to:

$$
R_{L}=R_{U}-L Y_{D} T^{*} \frac{1-T_{C}}{1-T^{*}}
$$

Both this simplified expression and the more complex formula in Equation (12) are approximations. Neither exactly reflects the actual leverage policies that firms follow, and it is not clear which is closer to the way that companies actually determine their leverage over time. Simplicity and ease of use thus favors Equation (14) rather than Equation (12) as the formula to use with risky debt and investor taxes. As we illustrate below, the numerical differences between these two formulas are likely to be small in practice.

\section{A. Differences Arising from Using Different Formulas}

To evaluate the extent of the differences arising from using various formulas, we examine three types of firms. These are shown in Table II, Panel A. The first firm, in Cases 1 and 4 , has a typical amount of leverage and a debt spread of $1 \%$. The second firm, shown in Cases 2 and 5, has higher leverage and a debt spread of $2 \%$. The third firm, in Cases 3 and 6 , has very high leverage and a debt spread of $3 \%$. All firms have an unleveraged cost of capital of $8 \%$. The general parameters are a riskless rate of $4 \%$, a corporate tax rate of $40 \%$, and a marginal investor tax rate on debt of $40 \%$. In Cases 1-3, the tax savings from debt, $T^{*}$, is the full corporate tax rate, whereas in Cases $3-6$, it is half the corporate tax rate. We compute $R_{L}$ from Equation (12) and compare the values given by other formulas.

Panel B demonstrates the differences resulting from the use of three other formulas. The first, shown in Row A, is the formula given in Brealey and Myers (1988) in Equation (8). When the tax savings is equal to the full corporate tax rate, this is identical to our formula. The main error in the formula arises because it does not treat investor taxes properly, which becomes an issue when $T^{*}$ does not equal $T_{C}$. This error is particularly large when the leverage is high. For example, in Case 6 , the error is a quarter of $1 \%$, enough to cause significant errors in company valuation. 
Table II. Differences Resulting from Different Formulas for $\boldsymbol{R}_{L}$

This table shows the differences arising from using different formulas to calculate the leveraged cost of capital, $R_{L}$. The unlevered cost of capital, $R_{U}$, is $8 \%$ and other variables are: $R_{F}=4 \%, T_{C}=40 \%, T_{P D}=$ $40 \%$. Panel A shows three different firms, with leverages of $30 \%, 60 \%$, and $80 \%$ and debt costs of $5 \%$, $6 \%$, and $7 \%$ respectively. The tax saving from interest, $T^{*}$, is assumed to be either $40 \%$ or $20 \%$, which is equivalent to setting $T_{P E}=40 \%$ or $20 \%$, respectively. The benchmark values of $R_{L}$ in Panel A are calculated using Equation (12). Panel B rows $\mathrm{A}, \mathrm{B}$, and $\mathrm{C}$ show the deviations in $R_{L}$ from the benchmark (alternative formula less benchmark) resulting from using the alternatives (8), (9), and (14), respectively.

\begin{tabular}{lrrrrrr}
\hline \hline & Case 1 & Case 2 & Case 3 & Case 4 & Case 5 & Case 6 \\
\hline \hline$L$ & $30 \%$ & $60 \%$ & $80 \%$ & $30 \%$ & $60 \%$ & $80 \%$ \\
$R_{D}$ & $5 \%$ & $6 \%$ & $7 \%$ & $5 \%$ & $6 \%$ & $7 \%$ \\
$T^{*}$ & $40 \%$ & $40 \%$ & $40 \%$ & $20 \%$ & $20 \%$ & $20 \%$ \\
Benchmark $R_{L}$ & $7.38 \%$ & $6.53 \%$ & $5.74 \%$ & $7.77 \%$ & $7.44 \%$ & $7.14 \%$ \\
\hline \hline
\end{tabular}

Panel B. Deviations from Benchmark $R_{L}$ Resulting from the Use of Different Formulas

\begin{tabular}{|c|c|c|c|c|c|c|}
\hline A. BM & $0.00 \%$ & $0.00 \%$ & $0.00 \%$ & $-0.07 \%$ & $-0.18 \%$ & $-0.27 \%$ \\
\hline B. Sick/Taggart & $0.12 \%$ & $0.47 \%$ & $0.93 \%$ & $0.04 \%$ & $0.18 \%$ & $0.35 \%$ \\
\hline C. Continuous approximation & $0.02 \%$ & $0.03 \%$ & $0.02 \%$ & $0.01 \%$ & $0.02 \%$ & $0.02 \%$ \\
\hline
\end{tabular}

Row B indicates the difference arising from using the Sick (1990) formula in Equation (9). This is the same as Taggart's (1991) formula in Equation (13) that assumes risk-free debt. Here the differences are larger, especially when the debt spread is high. For example, in Case 3 where the tax advantage to debt is at its maximum, the difference is almost a full percentage point. The difference occurs because of the different treatment of the debt spread, as discussed above.

Row $\mathrm{C}$ demonstrates the error when using continuous approximation in Equation (14) rather than the discrete formula in Equation (12). This error is small, indicating that the extra complexity of the formulas that assume discrete adjustment of leverage is unnecessary. The continuous expression in Equation (14) has the merits of being simple, very close to the discrete adjustment formula in Equation (12), and easy to use to convert $R_{L}$ to $R_{U}$ as well as vice versa.

\section{Implementation Using the CAPM}

A common approach is to use formulas for tax-adjusted discount rates in conjunction with the CAPM. For instance, we first estimate the equity beta and unlever it to get the asset beta, then calculate $R_{U}$ using the CAPM, and finally calculate $R_{L}$ using one of the formulas above. Alternatively, we calculate $R_{L}$ as the weighted average cost of capital by plugging equity and debt betas into the CAPM. From that we can infer $R_{U}$ and perhaps calculate new $R_{L}$ 's for different leverage ratios. In this section, we derive formulas for the implementation using the CAPM that are consistent with Equation (14).

\section{A. The CAPM with Investor Taxes}

The consensus investor will set returns so that the ratios of expected excess return to systematic risk of all assets are equal on an after-investor-tax basis. This means that the standard version 
of the CAPM, where returns and betas are measured before investor taxes, will be affected by investor tax rates. Appendix B reveals that the version of the CAPM that is consistent with the assumptions about tax that determine $T^{*}$ is:

$$
R_{E}=R_{F E}+\beta_{E} P
$$

where $R_{E}$ is the expected rate of equity return before investor taxes, $\beta_{E}$ is the beta of the equity, and

$$
P=R_{M}-R_{F E}
$$

Here $R_{M}$ is measured in the standard way, using returns before investor taxes. Betas are also measured in the standard way, using pre-tax returns. ${ }^{9}$

Note that only if $T^{*}=T_{C}$ (or, equivalently, $T_{P E}=\mathrm{T}_{P D}$ ), as assumed for the example in Modigliani and Miller (1963), is the standard version of the CAPM, with an intercept equal to $R_{F}$, valid. In contrast, the Miller (1977) view that $T^{*}=0$ corresponds to a CAPM where the intercept is $R_{F}\left(1-T_{C}\right)$. A similar effect can be seen in the formula for the required return on unlevered assets: ${ }^{10}$

$$
R_{U}=R_{F E}+\beta_{U} P
$$

As previously pointed out by Sick (1990) (see also Benninga and Sarig, 2003), the required return on debt follows a different version of the CAPM because the tax treatment of debt and equity differ in all cases other than the standard Modigliani and Miller (1963) case:

$$
R_{D}=R_{F}+\beta_{D} P \text {. }
$$

Regardless of the assumption about taxes, the pre-tax CAPM holds for debt as all debt is taxed in the same way. ${ }^{11}$

\section{B. The WACC and the Asset Beta}

The textbook $W A C C$ relationship is:

$$
W A C C_{\text {textbook }}=R_{D}\left(1-T_{C}\right) L+R_{E}(1-L) .
$$

\footnotetext{
${ }^{9}$ Describing the CAPM with Equations (15) and (16) assumes that the market portfolio consists of equities only. Alternatively, and perhaps more correctly, we could let the market portfolio exist of all risky assets. In this case, $P$ would have to be replaced by $\hat{P}=R_{M}^{\prime}-R_{F}\left(1-T_{P D}\right)$, where $R_{M}^{\prime}$ is the expected after-tax return on the market, and betas would have to be measured with respect to $\tilde{R}_{M}^{\prime}$. See Appendix B.

${ }^{10} \mathrm{Care}$ must be taken to distinguish between the unlevered beta, $\beta_{U}$, and the beta of the firm value given by the sum of debt and equity. The latter is affected by the beta of the tax savings, as we discuss below.

${ }^{11}$ One issue here, which Equation (18) ignores, is that in case of insolvency, there will be a capital loss on debt that will give rise to a tax savings equal to the loss $x$ the capital gains tax rate (as we have assumed in deriving Equation (12), where the capital gains tax rate is $T_{P E}$ ). The correct effective tax rate on risky debt is a weighted average between the tax rate on interest income, $T_{P D}$ and the capital gains rate. If we call this rate $\tau_{p d}$, then we would obtain the following pre-tax CAPM for risky debt: $R_{D}=R_{F D}+\beta_{D P}$, where $R_{F D}=R_{F}\left(1-T_{P D}\right) /\left(1-\tau_{p d}\right)$. There is another complexity with risky debt. It is not clear that the entire premium over the riskless rate is due to beta risk. We do not deal with this issue here. See Cooper and Davydenko (2007) for a discussion.
} 
This assumes that next period's expected tax saving to the corporation per unit of debt in the current period is $R_{D} T_{C}$. More generally, the tax saving is $Y_{D} T_{C}$ if the company is solvent, and less if it is not. Under the assumption underlying our analysis (see Section III), solvency occurs with probability $p$ and the tax saving is zero in case of insolvency. Thus, the correct WACC is

$$
W A C C=\left(R_{D}-p Y_{D} T_{C}\right) L+R_{E}(l-L)
$$

Furthermore, $\left(1+R_{D}\right)=p\left(1+Y_{D}\right)$. Using this relation, we can rewrite the formula for the $W A C C$ as

$$
W A C C=R_{D}\left(1-T_{C}\right) L+R_{E}(1-L)-\frac{Y_{D}-R_{D}}{1+Y_{D}} T_{C} L
$$

Notice that the third term is positive, but likely to be small in practice. ${ }^{12}$ Thus, the textbook WACC overstates the true $W A C C$ by a small term that depends on the probability of default, as reflected in the difference between the yield and the expected rate of return on the debt.

Under the ME assumptions, the WACC as given by Equation (20) is equal to $R_{L}$. Using the continuous rebalancing assumption (see Equation (14)):

$$
R_{D}\left(1-T_{C}\right) L+R_{E}(1-L)-\frac{Y_{D}-R_{D}}{1+Y_{D}} T_{C} L=R_{U}-L T^{*} Y_{D} \frac{1-T_{C}}{1-T^{*}}
$$

Now define $S_{D}$ to be the "yield spread," that is,

$$
S_{D} \equiv Y_{D}-R_{F}
$$

Using this definition and substituting $R_{E}, R_{U}$, and $R_{D}$ from Equations (15), (17), and (18), respectively, into (22), we get that the unlevered asset beta is

$$
\beta_{U}=\beta_{D} L \frac{1-T_{C}}{1-T^{*}}+\beta_{E}(1-L)-L\left(\frac{S_{D}}{P}-\beta_{D}\right)\left(\frac{T_{C}}{1+Y_{D}}-T^{*} \frac{1-T_{C}}{1-T^{*}}\right)
$$

where $P$ is the risk premium (as given in Equation (16)). The final term is small and can be ignored in most practical cases, resulting in the following formula for the asset beta:

$$
\beta_{U}=\beta_{D} L \frac{1-T_{C}}{1-T^{*}}+\beta_{E}(1-L)
$$

We suggest using this asset beta formula in the presence of personal taxes and risky debt. The approximation is better the lower is the difference between $Y_{D}$ and $R_{D}$; when these are equal, $S_{D} / P$ equals $\beta_{D}$ and the third term in Equation (24) is zero, thus giving Equation (25) exactly. If

\footnotetext{
${ }^{12}$ The third term in Equation (21) may have significant impact when leverage is "high," which may also be associated with a large difference between $Y_{D}$ and $R_{D}$.
} 
$T^{*}=T_{C}$ (or, equivalently $T_{P E}=T_{P D}$, see Equation (5)), Equation (25) is equal to the standard asset beta equation: ${ }^{13}$

$$
\beta_{U}=\beta_{D} L+\beta_{E}(1-L)
$$

We can intuitively understand the relationships between betas in the following way. The leveraged firm's operating assets are the same as those for the all-equity firm. But the leveraged firm generates extra value through the tax savings from interest and changes the after-tax risk of the cash flow by channeling some of it to debtholders rather than equityholders changing the associated tax treatment. The weighted average of the equity beta and the tax-adjusted debt beta for the leveraged firm must equal the asset beta adjusted for the effect of the tax savings:

$$
\frac{E}{V_{L}} \beta_{E}+\frac{D}{V_{L}} \beta_{D} \frac{1-T_{P D}}{1-T_{P E}}=\frac{V_{L}-V_{T S}}{V_{L}} \beta_{U}+\frac{V_{T S}}{V_{L}} \beta_{T S}
$$

where $E$ is the value of the equity, $D$ the value of the debt, $V_{L}=E+D, V_{T S}$ is the value of the tax shield, and $\beta_{T S}$ is its beta. The value $V_{L}-V_{T S}$ is the all-equity value of the firm, which has beta equal to $\beta_{U}$. The adjustment to the debt beta reflects the fact that the differential tax treatment of debt and equity results in a change in beta when cash flow is switched from equity to debt, even apart from the effect on the value of the firm. With the ME assumptions and continuous debt rebalancing, $\beta_{T S}$ is approximately equal to $\beta_{U}$, giving Equation (25). ${ }^{14}$

\section{Conclusion}

We have presented tax-adjusted discount rates and asset beta formulas with a constant debt to value leverage policy, investor taxes, and risky debt. We have compared our formula for taxadjusted discount rates with those of Miles and Ezzell (1980), who do not allow for investor taxes; Sick (1990) and Brealey and Myers (1988), who include both risky debt and investor taxes; and Taggart (1991), who assumes risk-free debt. Differences arise because of different assumptions about the tax system (Sick, 1990) or missing tax effects (Brealey and Myers, 1988). Using realistic parameter values, we have shown that differences between these formulas can be almost a full percentage point at high leverage levels. Given our assumptions, the correct formula, assuming discrete rebalancing of debt, is complex. However, the approximation based on continuous rebalancing is very accurate:

$$
R_{L}=R_{U}-L Y_{D} T^{*} \frac{1-T_{C}}{1-T^{*}} .
$$

This approximation has the merits of being simple, very close to the discrete adjustment formula, and easy to use to convert $R_{L}$ to $R_{U}$ as well as vice versa. We have also presented the formulas

\footnotetext{
${ }^{13}$ Further to the discussion in Footnote 9, note that Equation (26) does not rely on an assumption that the market portfolio consists only of equities. For when $T_{P E}=T_{P D}$, the CAPM is described by Equations (15) and (16), also when the market portfolio includes debt, and $R_{F E}=R_{F}$.

${ }^{14}$ In general, with the ME debt policy, $\beta_{T S}$ and $\beta_{U}$ are not equal due to discrete rebalancing and also the effect of debt default (Sick, 1990). With continuous rebalancing, $\beta_{T S}$ and $\beta_{U}$ will be approximately equal. However, the effect of default still may cause a small difference, as reflected by the extra (third) term in Equation (24).
} 
for asset betas and implementation using the CAPM that are consistent with this. The formula we suggest for the asset beta in the presence of personal taxes is

$$
\beta_{U}=\beta_{D} L \frac{1-T_{C}}{1-T^{*}}+\beta_{E}(1-L)
$$

This is consistent with Equation (28) when a small term involving the difference between the promised yield and expected return on debt is ignored.

These results are based on the assumption that the firm does not pay tax on the write-off of its debt if it defaults. The alternative assumption, that it does pay this tax, results in the formulas given by Sick (1990). Which formula is appropriate in a given situation depends, to a large extent, on the tax treatment of COD. As we have discussed, in the United States, there is no tax on COD for firms that are legally insolvent. Thus, in a US context, the approach taken in this paper is arguably the appropriate one. Our formulas assume complete insolvency (i.e., complete cancellation of debt). An important avenue for further research is to accommodate partial default into a framework where there is no tax on COD.

\section{Appendix A: Proof of the Relationship between $R_{L}$ and $R_{U}$}

We prove the relationship between $R_{L}$ and $R_{U}$ by induction. Let $T$ be the terminal date of the firm and denote the expected, as of date $T-1$, cash flow at date $T$ by $C_{T}$. At date $T-1$, the ex-cash flow unleveraged value is

$$
V_{U T-1}=C_{T}\left(1-T_{C}\right) /\left(1+R_{U}\right)
$$

Note that the expected after-tax cash flow to investors at date $T$ is

$$
C_{T}\left(1-T_{C}\right)\left(1-T_{P E}\right)+V_{U T-1} T_{P E}
$$

The second term represents the after-tax cash flow arising from the tax deduction associated with the purchase price, $V_{U T-1}$, at date $T-1$. We assume that if there is a capital loss on the investment in the current firm, the investor can use this to offset gains elsewhere. This tax deduction is implicitly taken care of by $R_{U}$ in Equation (A1).

Note that we are assuming that capital gains taxes are paid on a mark-to-market basis and that the same tax rate applies to capital gains and dividends. The use of separate tax rates on capital gains and equity income would complicate the analysis at this point, as would the use of an "as-realized" rule for capital gains. The implications of different capital gains and income taxation are not our main focus, so we use the most simple assumption. ${ }^{15}$

In the levered case, there are two additional sources of cash flows. First, there is the tax saving from the tax deductibility of interest payments. This equals $Y_{D} L V_{L T-1} T_{S}$ in case of solvency and zero otherwise. Under our assumptions, this is valued by replicating the after-tax cash flows for the investor using a combination of the risky bond and the riskless asset. Using the procedure in Table I, but including investor taxes, gives the value shown as the second term in Equation (A3)

\footnotetext{
${ }^{15}$ There is an emerging literature that introduces realistic treatment of capital gains taxes into the capital structure literature (see Lewellen and Lewellen, 2005). The implications of their results for practical valuation are not yet clear.
} 
as the value of the interest tax shield. ${ }^{16}$ Second, investors get an extra tax deduction from capital gains of $V_{L T-1}-V_{U T-1}$, the difference between the tax basis of the levered and unlevered firms. This gives rise to an extra after-tax cash flow of $\left(V_{L T-1}-V_{U T-1}\right) T_{P E}$, using a capital gains tax rate of $T_{P E}$. Since this is riskless, it should be discounted at $R_{F}\left(1-T_{P D}\right)$. The value of the levered firm is therefore:

$$
V_{L T-1}=V_{U T-1}+\frac{L V_{L T-1} Y_{D} T_{S}\left(1+R_{F}\right)}{\left(1+Y_{D}\right)\left(1+R_{F}\left(1-T_{P D}\right)\right)}+\frac{\left(V_{L T-1}-V_{U T-1}\right) T_{P E}}{1+R_{F}\left(1-T_{P D}\right)} .
$$

Using Equations (4) and (6), we can rearrange Equation (A3) as:

$$
V_{L T-1}=V_{U T-1}+\frac{L V_{L T-1} T^{*} Y_{D}\left(1-T_{C}\right)\left(1+R_{F}\right)}{\left(1+Y_{D}\right)\left(1-T^{*}\right)\left(1+R_{F E}\right)}
$$

At time $T-1, R_{L}$ and $R_{U}$ are defined by:

$$
\left(1+R_{L}\right)=C_{T}\left(1-T_{C}\right) / V_{L T-1}
$$

$$
\left(1+R_{U}\right)=C_{T}\left(1-T_{C}\right) / V_{U T-1}
$$

Thus, $V_{U T-1}=V_{L T-1}\left(1+R_{L}\right) /\left(1+R_{U}\right)$. Substituting this into (A4), we get:

$$
R_{L}=R_{U}-\left[L Y_{D} T^{*}\left(1+R_{U}\right) /\left(1+Y_{D}\right)\right]\left[\left(1-T_{C}\right) /\left(1-T^{*}\right)\right]\left[\left(1+R_{F}\right) /\left(1+R_{F E}\right)\right] .
$$

We will now establish the generality of this formula. Consider first time $T-2$. Consider the expected cash flow at $T-1, C_{T-1}$, and the continuation value, $V_{L T-1}$, as two separate, but equally levered flows. Denote their values at $T-2$ by $w_{T-2}$ and $W_{T-2}$, respectively. The same argument as above establishes that $w_{T-2}=C_{T-1}\left(1-T_{C}\right) /\left(1+R_{L}\right)$, with $R_{L}$ given by Equation (A7). Now, we have established above that $V_{L T-1}$ is proportional to $V_{U T-1}$. Therefore, its unleveraged value at $T-2$ is $V_{L T-1} /\left(1+R_{U}\right)$. Thus, using the same argument as above, the leveraged value of $V_{L T-1}$ at $T-2$ is $W_{T-2}=V_{L T-1} /\left(1+R_{L}\right)$, with $R_{L}$ given by Equation (A7). This establishes that:

$$
V_{L T-2}=\frac{C_{T-1}\left(1-T_{C}\right)}{1+R_{L}}+\frac{C_{T}\left(1-T_{C}\right)}{\left(1+R_{L}\right)^{2}}
$$

This argument can be repeated for arbitrary $T-t$, which establishes the generality of Equation (A7).

\section{Appendix B. Relationships between Betas and Returns}

The representative investor sets returns so that after-tax returns are in equilibrium. However, the CAPM is usually stated in terms of pre-tax betas and risk premia. This appendix uses the

\footnotetext{
${ }^{16}$ The replicating portfolio is now: $T_{S} Y_{D} /\left[\left(1+Y_{D}\right)\left(1-T_{P D}\right)\right]$ in the risky bond, and $-\left[T_{S} Y_{D} T_{P D} /\left[\left(1+Y_{D}\right)\left(1-T_{P D}\right)(1+\right.\right.$ $\left.\left.R_{F}\left(1-T_{P D}\right)\right)\right]$ in the risk-free bond. Adding these two quantities gives the reported value of the tax deductibility of interest payments (since the risky and riskless bonds both have a price of 1 ).
} 
after-tax CAPM to derive the pre-tax version that is consistent with the assumptions about the tax saving on debt.

Equilibrium requires that expected rates of return are the same after tax for all investments with the same exposure to systematic risk. Specifically, the after-tax CAPM implies that:

$$
\begin{aligned}
& R_{E}\left(1-T_{P E}\right)=R_{F}\left(1-T_{P D}\right)+\beta_{E}^{\prime} P^{\prime} \\
& R_{U}\left(1-T_{P E}\right)=R_{F}\left(1-T_{P D}\right)+\beta_{U}^{\prime} P^{\prime} \\
& R_{D}\left(1-T_{P D}\right)=R_{F}\left(1-T_{P D}\right)+\beta_{D}^{\prime} P^{\prime},
\end{aligned}
$$

where $P^{\prime}$ is the post-tax market risk premium:

$$
P^{\prime}=R_{M}^{\prime}-R_{F}\left(1-T_{P D}\right)
$$

$R_{M}^{\prime}$ is the post-tax return on the market portfolio (which would include equities as well as risky debt). Betas in Equation (B1) are written with a prime to indicate that they are post-tax betas. have:

Denoting betas of pre-tax returns with respect to the post-tax market portfolio by a "hat," we

$$
\beta_{E}^{\prime}=\frac{\operatorname{Cov}\left(\tilde{R}_{E}\left(1-T_{P E}\right), \tilde{R}_{M}^{\prime}\right)}{\operatorname{Var}\left(\tilde{R}_{M}^{\prime}\right)}=\left(1-T_{P E}\right) \frac{\operatorname{Cov}\left(\tilde{R}_{E}, \tilde{R}_{M}^{\prime}\right)}{\operatorname{Var}\left(\tilde{R}_{M}^{\prime}\right)} \equiv\left(1-T_{P E}\right) \hat{\beta}_{E}
$$

Here $\hat{\beta}_{E}$ is the beta of the pre-tax return on equity with respect to the after-tax return on the market. Similarly:

$$
\beta_{U}^{\prime}=\left(1-T_{P E}\right) \hat{\beta}_{U}
$$

and

$$
\beta_{D}^{\prime}=\frac{\operatorname{Cov}\left(\tilde{R}_{D}\left(1-T_{P D}\right), \tilde{R}_{M}^{\prime}\right)}{\operatorname{Var}\left(\tilde{R}_{M}^{\prime}\right)}=\left(1-T_{P D}\right) \frac{\operatorname{Cov}\left(\tilde{R}_{D}, \tilde{R}_{M}^{\prime}\right)}{\operatorname{Var}\left(\tilde{R}_{M}^{\prime}\right)} \equiv\left(1-T_{P D}\right) \hat{\beta}_{D}
$$

Using these betas provides the following expressions for the pre-tax returns on equity and debt:

$$
\begin{aligned}
& R_{E}=R_{F E}+\hat{\beta}_{E} P^{\prime} \\
& R_{U}=R_{F E}+\hat{\beta}_{U} P^{\prime} \\
& R_{D}=R_{F}+\hat{\beta}_{D} P^{\prime}
\end{aligned}
$$

Most empirical observations about risk premia are made in terms of pre-tax returns. Going from $P^{\prime}$ to a pre-tax risk premium is clearly not straightforward when the market portfolio consists of assets that are taxed at different rates.

As a simplification, let us assume that the market portfolio (i.e., the priced factor) consists only of equities. Then: 
$P^{\prime}=R_{M}\left(1-T_{P E}\right)-R_{F}\left(1-T_{P D}\right)=R_{M}\left(1-T_{P E}\right)-R_{F E}\left(1-T_{P E}\right)$,

where $R_{M}$ is the pre-tax expected rate of return on the market portfolio. Furthermore,

$$
\hat{\beta}_{E}=\frac{\operatorname{Cov}\left(\tilde{R}_{E}, \tilde{R}_{M}\left(1-T_{P E}\right)\right)}{\operatorname{Var}\left(\tilde{R}_{M}\left(1-T_{P E}\right)\right)}=\frac{1}{1-T_{P E}} \frac{\operatorname{Cov}\left(\tilde{R}_{E}, \tilde{R}_{M}\right)}{\operatorname{Var}\left(\tilde{R}_{M}\right)} \equiv \frac{1}{1-T_{P E}} \beta_{E},
$$

where $\beta_{E}$ is the beta of the pre-tax return on equity with respect to the pre-tax return on the market. This is the beta one normally works with in most applications. Similarly:

$$
\hat{\beta}_{U}=\frac{1}{1-T_{P E}} \beta_{U}
$$

and

$$
\hat{\beta}_{D}=\frac{1}{1-T_{P E}} \frac{\operatorname{Cov}\left(\tilde{R}_{D}, \tilde{R}_{M}\right)}{\operatorname{Var}\left(\tilde{R}_{M}\right)} \equiv \frac{1}{1-T_{P E}} \beta_{D} .
$$

Substituting into (B5)-(B7), we get:

$$
\begin{aligned}
& R_{E}=R_{F E}+\beta_{E} P \\
& R_{U}=R_{F E}+\beta_{U} P \\
& R_{D}=R_{F}+\beta_{D} P,
\end{aligned}
$$

where:

$$
P=R_{M}-R_{F E}
$$

is the equity risk premium based on pre-tax returns on the market. Note, however, that the premium is measured relative to the tax-adjusted riskless equity rate, $R_{F E}$, rather than the pre-tax rate $R_{F}$.

\section{References}

Benninga, S. and O. Sarig, 2003, "Risk, Returns, and Values in the Presence of Differential Taxation," Journal of Banking and Finance 27, 1123-1138.

Betker, B., 1995, “An Empirical Examination of Prepackaged Bankruptcy,” Financial Management 24, 3-18.

Brealey, R.A. and S.C. Myers, 2003, Principles of Corporate Finance, 7th ed., New York, NY, McGraw-Hill.

Brealey, R.A. and S.C. Myers, 1988, Principles of Corporate Finance, 3rd ed., New York, NY, McGraw-Hill.

Cooper, I.A. and S. Davydenko, 2007, "Estimating the Cost of Risky Debt," Journal of Applied Corporate Finance 19, 81-86.

Cooper, I.A. and K.G. Nyborg, 2006, "The Value of Tax Shields is Equal to the Present Value of Tax Shields," Journal of Financial Economics 81, 215-225. 
Emery, D.R. and A.K. Gehr, Jr., 1988, "Tax Options, Capital Structure, and Miller Equilibrium: A Numerical Illustration," Financial Management 17, 30-40.

Fama, E.F. and K.R. French, 1998, "Taxes, Financing and Firm Value," Journal of Finance 53, 879-843.

Fernandez, P., 2004, "The Value of Tax Shields is Not Equal to the Present Value of Tax Shields," Journal of Financial Economics 73, 145-165.

Gilson, S.C., 1997, "Transactions Costs and Capital Structure Choice: Evidence from Financially Distressed Firms," Journal of Finance 52, 161-196.

Graham, J.R., 2000, "How Big are the Tax Benefits of Debt?" Journal of Finance 55, 1901-1941.

Kemsley, D. and D. Nissim, 2002, "Valuation of the Debt Tax Shield," Journal of Finance 57, 2045-2073.

Lewellen, J. and K. Lewellen, 2005, "Taxes and Financial Decisions," Massachusetts Institute of Technology Working Paper.

Miles, J. and J.R. Ezzell, 1980, "The Weighted Average Cost of Capital, Perfect Capital Markets and Project Life: A Clarification," Journal of Financial and Quantitative Analysis 15, 719-730.

Miller, M.H., 1991, "Tax Obstacles to Voluntary Corporate Restructuring," Journal of Applied Corporate Finance 4, 20-23.

Miller, M.H., 1977, "Debt and Taxes," Journal of Finance 32, 261-276.

Modigliani, F. and M.H. Miller, 1963, "Corporate Income Taxes and the Cost of Capital: A Correction," American Economic Review 53, 433-443.

Rajan, R.G. and L. Zingales, 1995, "What Do We Know about Capital Structure? Some Evidence from International Data," Journal of Finance 50, 1421-1460.

Sick, G.A., 1990, “Tax-Adjusted Discount Rates," Management Science 36, 1432-1450.

Taggart, R.A., 1991, "Consistent Valuation and Cost of Capital Expressions with Corporate and Personal Taxes," Financial Management 20, 8-20.

United States Tax Court, Judge Goeke, 2006, T.C. Memo. 2006-61, Docket No. 5213-04, Mazhar Tabrezi, f.k.a. Agha Hussain, and Sajida Razvi, Petitioners v. Commissioner of Internal Revenue, Respondent. 
Copyright of Financial Management (Blackwell Publishing Limited) is the property of Blackwell Publishing Limited and its content may not be copied or emailed to multiple sites or posted to a listserv without the copyright holder's express written permission. However, users may print. download, or email articles for individual use. 